\title{
Former Oral Contraceptive User
}

National Cancer Institute

\section{Source}

National Cancer Institute. Former Oral Contraceptive User. NCI Thesaurus. Code C157412.

An individual who previously used oral contraceptives. 